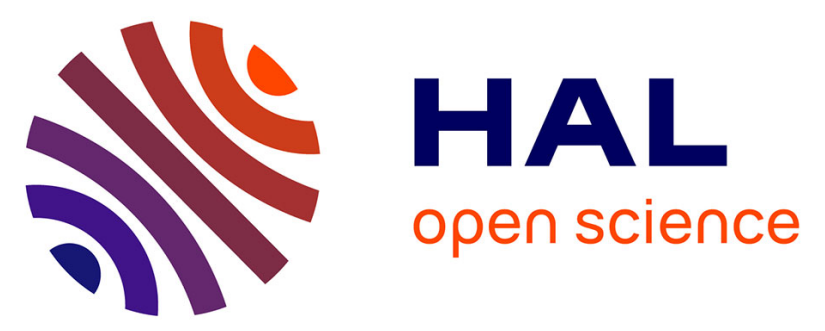

\title{
Radiative and heat storage properties of the urban fabric derived from analysis of surface forms
}

Anne Bernabé, Jérémy Bernard, Marjorie Musy, Hervé Andrieu-, Erwan Bocher, Isabelle Calmet, Pascal Kéravec, Jean Michel Rosant

\section{- To cite this version:}

Anne Bernabé, Jérémy Bernard, Marjorie Musy, Hervé Andrieu-, Erwan Bocher, et al.. Radiative and heat storage properties of the urban fabric derived from analysis of surface forms. Urban Climate, 2015, 12, pp.205-218. 10.1016/j.uclim.2015.04.001 . hal-01141712v2

HAL Id: hal-01141712

https://hal.science/hal-01141712v2

Submitted on 31 May 2018

HAL is a multi-disciplinary open access archive for the deposit and dissemination of scientific research documents, whether they are published or not. The documents may come from teaching and research institutions in France or abroad, or from public or private research centers.
L'archive ouverte pluridisciplinaire HAL, est destinée au dépôt et à la diffusion de documents scientifiques de niveau recherche, publiés ou non, émanant des établissements d'enseignement et de recherche français ou étrangers, des laboratoires publics ou privés. 


\section{Radiative and heat storage properties of the urban fabric derived from analysis of surface forms}

\section{Authors}

Anne Bernabé - anne.bernabe@ec-nantes.fr

Institut de Recherche en Sciences et Techniques de la Ville - FR CNRS 2488, France- Laboratoire de recherche en Hydrodynamique, Énergétique et Environnement Atmosphérique - UMR CNRS 6598, France

Jérémy Bernard - jeremy.bernard@cerma.archi.fr

Institut de Recherche en Sciences et Techniques de la Ville - FR CNRS 2488, FR - Centre de recherche méthodologique d'architecture - UMR CNRS 1563, France - ADEME, France

Marjorie Musy - marjorie.musy@ec-nantes.fr

Institut de Recherche en Sciences et Techniques de la Ville - FR CNRS 2488, FR - Centre de recherche méthodologique d'architecture - UMR CNRS 1563, France

Hervé Andrieu - herve.andrieu@ifsttar.fr

Institut de Recherche en Sciences et Techniques de la Ville - FR CNRS 2488, France - Institut français des sciences et technologies des transports, de l'aménagement et des réseaux

Erwan Bocher - erwan.bocher@ec-nantes.fr

Institut de Recherche en Sciences et Techniques de la Ville - FR CNRS 2488, France

Isabelle Calmet - isabelle.calmet@ec-nantes.fr

Institut de Recherche en Sciences et Techniques de la Ville - FR CNRS 2488, France- Laboratoire de recherche en Hydrodynamique, Énergétique et Environnement Atmosphérique - UMR CNRS 6598, France

Pascal Kéravec - pascal.keravec@ec-nantes.fr

Institut de Recherche en Sciences et Techniques de la Ville - FR CNRS 2488, France- Laboratoire de recherche en Hydrodynamique, Énergétique et Environnement Atmosphérique - UMR CNRS 6598, France

Jean-Michel Rosant - Jean-Michel.Rosant@ec-nantes.fr

Institut de Recherche en Sciences et Techniques de la Ville - FR CNRS 2488, France- Laboratoire de recherche en Hydrodynamique, Énergétique et Environnement Atmosphérique - UMR CNRS 6598, France 


\title{
Highlight
}

- Urban albedo is computed at city block scale from solar simulations.

- Temperature signal time shift is calculated from three years of measurements.

- Urban albedo is strongly related to sky view factor and facade density.

- Temperature signal time shift is explained by aspect ratio $\mathrm{H} / \mathrm{W}$ and facade density.

- Climatic maps could be directly produced from geographical data.

\begin{abstract}
Radiative balance and heat storage capacity modifications play a major role in urban heat island formation. Urban shape determines the receipt and loss of radiation and consequently the heat storage potential, thus resulting in a higher air temperature.

In order to analyze the interactions between climate and urban shape, the territory is partitioned from the road network into elementary areas: the city blocks.

Nine geographical and two climatic indicators are computed at city block scale. The geographical ones are produced thanks to OrbisGIS platform from geographical data supplied by the French IGN. The first climatic indicator, the urban albedo, is computed from solar simulations with Solene model on 230 city blocks to characterize the radiative balance. The second one, the air temperature time shift, is calculated from three years of measurements between eight city blocks and a reference sites to characterize the heat storage properties of the urban fabric.
\end{abstract}

Relationships between those climatic and geographical indicators are investigated using linear regression analysis. Facade density is the geographical indicator which best explains both radiative and heat storage properties at city block scale. From the relationships identified previously and geographical data, climatic maps are produced to assess urban vulnerability to climate change.

Keywords: Urban heat island, Climatic indicator, Climatic map, Geographical Information System, Geographical indicator, City block 


\section{Introduction}

The combination of global warming and the Urban Heat Island (UHI) makes cities and the urban population particularly vulnerable to climate change and necessitates different adaptation measures. Usually, adaptation strategies assessment is based on a modeling approach of the interactions between local climate and urban environment (Masson et al. 2014). Several models are available and require a rather complete set of data: building geometry and their close surroundings, energy consumption practices and a large panel of climatic conditions. Consequently, it is a challenge to transfer climatic knowledge to institutional stakeholders and urban planners. A better understanding of interactions between urban environment and local climate conditions will provide city planning strategies for improving urban thermal environment.

Oke (1987) observed that the UHI spatial structure is strongly related to urban forms. Several others studies identified relationships between urban climate and local geographical indicators, for instance:

- The urban albedo (indicator of the solar radiation balance) of plot configurations decreases with increasing building height (Kondo et al. 2001). Moreover, Groleau and Mestayer (2013) showed that urban albedo values strongly depend on both building and facade density.

- The loss of longwave radiation to the sky as well as the turbulent heat transfers are reduced when the sky view factor decreases (Unger 2004).

- The Bowen ratio (ratio between sensible heat and latent heat) increases when the percentage of land covered by vegetation decreases (Musy et al. 2012).

- Nighttime air temperature increases with increasing of building density during summertime (Yan et al. 2014).

- There is a strong linear connection between the areal average of sky view factor and the annual mean UHI intensity (Gal et al. 2009)

Schwarz et al. (2012) showed that radiative balance (solar radiation trapping) and heat storage properties (thermal inertia) modifications play a major role on UHI formation. The net 
solar radiation give the amount of solar energy introduced into the urban thermodynamic system and partially transformed into sensible heat (Groleau and Mestayer 2013). Arnfield and Grimmond (1998) demonstrated that the heat storage flux is a significant term in the energy disposition of an urban canyon.

The purpose of this study is to identify the main geographical indicators responsible for the radiative balance and heat storage properties of the urban fabric. Two ascertainments must be made from existing studies. (1) Morphology influence on the net solar radiation balance is mostly investigated on generic simplified geometries and the results are sometimes unobvious to transpose to urban planning. (2) The inertia phenomenon is often calculated as the result of a heat balance but is rarely highlighted through a direct measurement analysis.

In order to analyze the interactions between climate and urban shape, the territory is partitioned from the road network into elementary areas: the city blocks. Nine geographical and two climatic indicators are computed at city block scale. The geographical ones are produced thanks to OrbisGIS platform (Bocher and Petit 2012) from geographical data supplied by the French IGN.

The first climatic indicator, the urban albedo, is computed from solar simulations with the Solene model on 230 city blocks to characterize the radiative balance. The second one, the air temperature time shift, is calculated from three years of measurements between eight city blocks and a reference sites to characterize the heat storage properties of the urban fabric. « [This indicator] is driven by [both] the net longwave radiation loss and [...] by the ability of the subsurface materials to release their store of heat » (Spronken-Smith and Oke 1999). Relationships between those climatic and geographical indicators are investigated using linear regression analysis. From the relationships identified and geographical data, climatic maps can be produced to assess the urban vulnerability to UHI. That will provide support to include urban climate considerations in the institutional stakeholder's practices. The overall process analysis is illustrated in Figure 1. 
The methods developed to produce geographical and climatic indicators are described in Section 2. The results of the analysis as well as the improvement perspectives are presented in Section 3. Finally conclusions are given in Section 4.

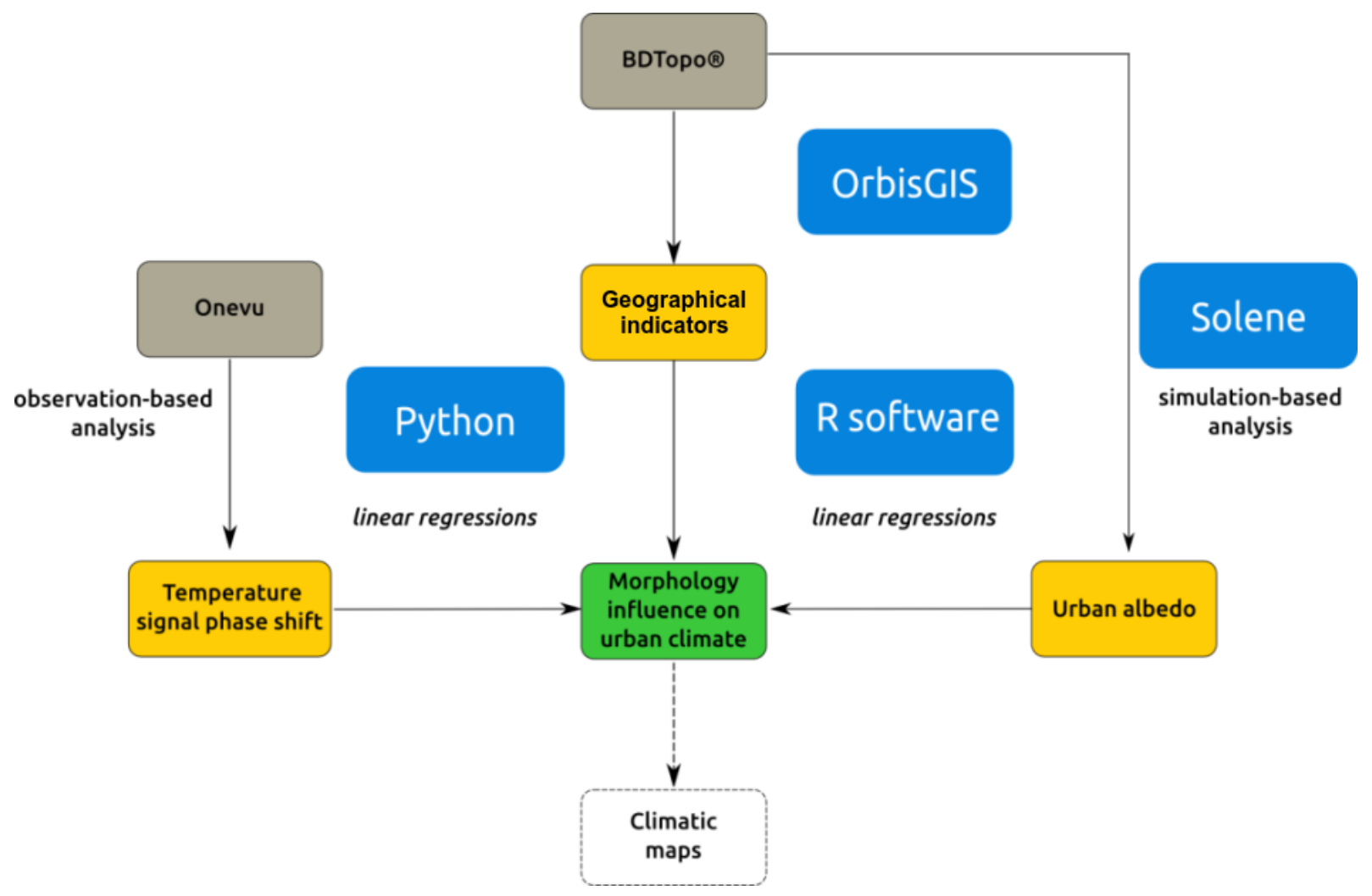

Figure 1. Overall process analysis. Blue: tools, Grey: input databases, Yellow: indicators

\section{Indicators computation}

The studied area of Nantes is partitioned from the road network into elementary spatial units: the city blocks. Nine geographical and two climatic indicators are computed at city block scale. The methods developed to produce geographical and climatic indicators are described here.

\subsection{Geographical and climatic context}

Nantes $\left(47^{\circ} 13^{\prime} \mathrm{N}, 1^{\circ} 34^{\prime} \mathrm{W}\right)$ is located on the Loire River on the west of France, $50 \mathrm{~km}$ far from the Atlantic coast. It is the 6th largest city in France with a total population in its metropolitan 
area of 590000 inhabitants in $2010^{1}$. Nantes has a Western European oceanic climate, with a mild, windy and humid winter and a relatively mild summer. January is the coldest month with an average minimum temperature of $2.9{ }^{\circ} \mathrm{C}$ and an average maximum of $9.9{ }^{\circ} \mathrm{C}$. August is the warmest with an average minimum temperature of $14.2{ }^{\circ} \mathrm{C}$ and an average maximum of $25{ }^{\circ} \mathrm{C}$. The highest temperature in 1981-2010 was $39.2{ }^{\circ} \mathrm{C}$ during the heat wave of 2003. Sunshine

average is 1791 hours per year ${ }^{2}$. The main wind directions are from the north, the northwest and the west. Although Nantes has a mild summer climate, it is important to think the city looking ahead. And in the future « the length, frequency, and/or intensity of warm spells or heat waves are assessed to be very likely to increase throughout the whole [Europe] » (Stocker et al. 2013).

\subsection{Elementary spatial unit: the city block}

In order to analyze the interactions between climate and urban shape, the territory is partitioned into elementary areas: the « city blocks » (Lesbegueries et al. 2009). This partitioning is generic and automatic: morphologically homogeneous city blocks are defined from the road network as illustrated in Figure 2 to respect the spatial organization of the city and the building configurations.

\footnotetext{
${ }^{1}$ http://www.nantesmetropole.fr/la-communaute-urbaine/24-communes

2 http://www.meteofrance.com/climat/france-/bouguenais/44020001/normales
} 


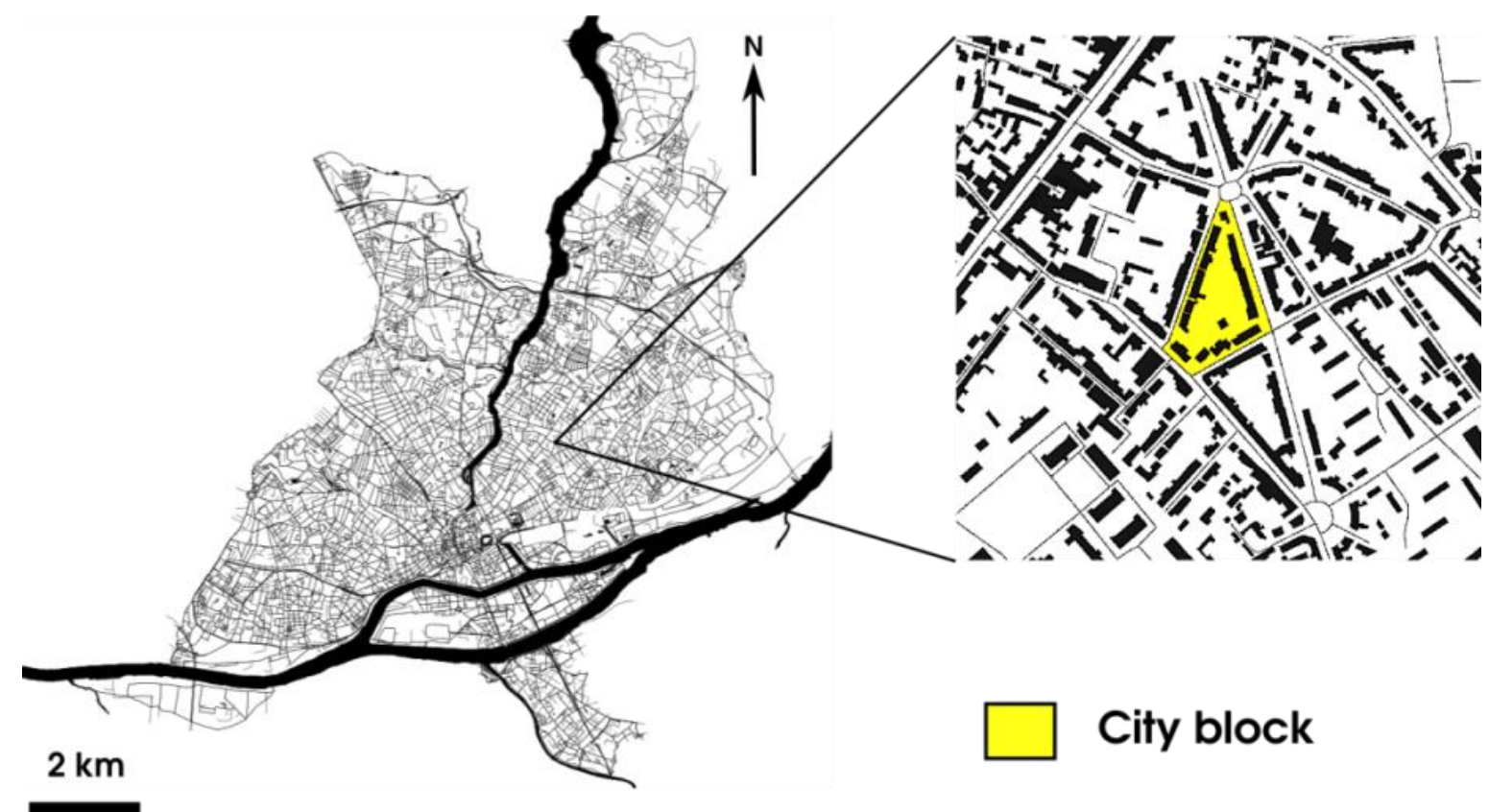

Figure 2. Nantes partition from road network and « city blocks » identification

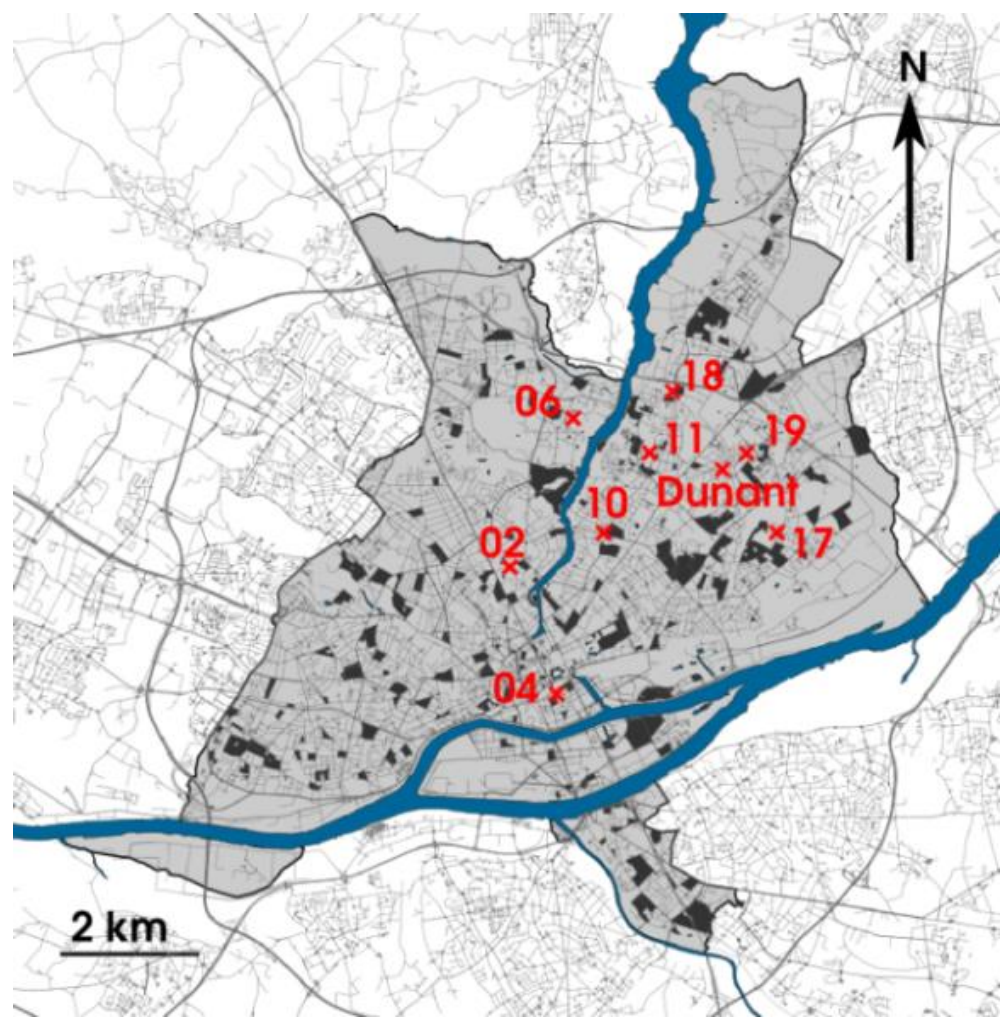

Figure 3. Study area - Nantes. Black: selected city blocks for simulation, Red crosses: measurement sites 
The study area covers $65.19 \mathrm{~km} 2$. It is divided in more than 2300 city blocks. Aiming at characterizing the radiative behavior of the whole city, a random sample of 230 city blocks (highlighted in black on Figure 3) is selected in Nantes, comprising 10\% of the urban area. A complete solar radiation calculation is performed on each city block. Originally, measurements stations were disposed for an experimental survey of a small watershed (Ruban et al. 2007). The temperature and relative humidity measurements have been later extended to a larger part of the city, as illustrated in Figure 3 (red crosses). A description of the measurement sites is given in Table 1. The sensors use the technology Hygroclip $\mathrm{S}^{3}$ (accuracy $+-0.3 \mathrm{~K}$ at $23^{\circ} \mathrm{C}$ ) and they are mounted with a cylindric $(85 \times 90 \mathrm{~mm} 3)$ shield protection against solar radiation (using natural ventilation).

Table 1. Description of the measurement sites

\begin{tabular}{|c|c|c|c|c|c|}
\hline Name & $\mathbf{W}$ & $\mathbf{N}$ & $\begin{array}{c}\text { Elevation from } \\
\text { sea level /m }\end{array}$ & $\begin{array}{l}\text { Elevation from } \\
\text { ground level /m }\end{array}$ & Location \\
\hline TRH02 & $1^{\circ} 33^{\prime} 33.70$ & $47^{\circ} 13^{\prime} 46.95$ & 27 & 2 & Private house - on a wall \\
\hline TRH04 & $1^{\circ} 32^{\prime} 56.70$ & $47^{\circ} 12^{\prime} 48.54$ & 8 & 4.5 & Private house - on a wall \\
\hline TRH06 & $1^{\circ} 32^{\prime} 56.19$ & $47^{\circ} 14^{\prime} 58.72$ & 27 & 2 & Engineer school - on a pole \\
\hline TRH10 & $1^{\circ} 32^{\prime} 30.85$ & $47^{\circ} 14^{\prime} 05.57$ & 24 & 5 & Private house - on a wall \\
\hline TRH11 & $1^{\circ} 32^{\prime} 02.46$ & $47^{\circ} 14^{\prime} 44.54$ & 22 & 2.5 & Administration building - on a wall \\
\hline TRH17 & $1^{\circ} 30^{\prime} 32.20$ & $47^{\circ} 14^{\prime} 10.38$ & 13 & 3 & $\begin{array}{l}\text { Administration building - on a pole } \\
\text { surrounded by trees }\end{array}$ \\
\hline TRH18 & $1^{\circ} 31^{\prime} 49.55$ & $47^{\circ} 15^{\prime} 13.59$ & 25 & 2 & Administration building - on a wall \\
\hline TRH19 & $1^{\circ} 30^{\prime} 56.22$ & $47^{\circ} 14^{\prime} 46.89$ & 21 & 3 & Public garden - on a wall \\
\hline Dunant & $1^{\circ} 31^{\prime} 11.84$ & $47^{\circ} 14^{\prime} 38.47$ & 22 & 14 & Private offices - On a mast on a roof \\
\hline
\end{tabular}

\footnotetext{
${ }^{3}$ http://www.wittich.nl/EN/PDF/temhum/transmitters/HygroClip_S.pdf
} 


\subsection{Geographical indicators}

The geographical indicators that are expected to have a significant influence on urban climate are computed from geographical data produced by the French IGN (national geographical and forest institute): the topographical database called BDTopo ${ }^{\circledR}$. It is composed of different thematic layers (buildings, vegetation, hydrography, etc.) and provides information at building scale (height, building types, etc.). This database is standardized on the French territory ${ }^{4}$ which makes our method applicable to other cities.

Based on a literature review, we have collected studies that prove the impact of urban forms on climatic parameters and take inventory of relevant geographical indicators (Long and Kergomard 2005; Berghauser Pont and Haupt 2005; Groleau and Mestayer 2013, Bonhomme et al. 2014). More than 20 indicators can be computed from BDTopo®. Those indicators are calculated for each city block using Structured Query Language (SQL) requests within OrbisGIS interface (Bocher and Petit 2012) ${ }^{5}$. The geographical indicators which depend on the availability and accuracy of urban data are excluded. Vegetation density is an example of excluded indicators because this data is not homogeneously accurate at the city scale. In order to identify the most significant indicators, a Principal Component Analysis (PCA) is performed with the open source statistical software $\mathrm{R}^{6}$. According to the PCA results, some of the indicators are removed (for example the mean building orientation, mostly east-west) because they are not relevant. Nine significant geographical indicators (which are all morphological indicators) are finally selected and are presented in Table 2. The averages and the standard deviation values obtained for the whole studied area are given in Table 3. The ones obtained for the sample of 230 city blocks (previously selected in 2.2) are representative of the total area (see italic fields in Table 3).

\footnotetext{
${ }^{4} \mathrm{http}: / /$ professionnels.ign.fr/bdtopo

5 http://www.orbisgis.org/

6 http://www.r-project.org/
} 
Table 2. Implemented geographical indicators

\begin{tabular}{|c|c|c|c|c|}
\hline Symbol & Indicators & Description & Inputs & Formula \\
\hline $\mathrm{A}_{\mathrm{REF}}$ & City block area & Plan area bounded by the road network & - & $A_{\text {REF }}$ \\
\hline $\mathrm{H}$ & $\begin{array}{l}\text { Average building } \\
\text { height }\end{array}$ & $\begin{array}{l}\text { Ratio of the sum of building height }\left(\mathrm{h}_{\mathrm{i}}\right) \text { area } \\
\text { weighted to the total building area }\left(\mathrm{a}_{\mathrm{b}_{\mathrm{i}}}\right) \text {. }\end{array}$ & $\mathrm{h}_{\mathrm{i}}$ & $\mathrm{H}=\frac{\sum \mathrm{h}_{\mathrm{i}} \mathrm{a}_{\mathrm{b}_{\mathrm{i}}}}{\sum \mathrm{a}_{\mathrm{b}_{\mathrm{i}}}}$ \\
\hline W & $\begin{array}{l}\text { Average street } \\
\text { width }\end{array}$ & $\begin{array}{l}\text { Open space surface is assumed to be a rectangle. } \\
\text { The average open space width is deduced from the } \\
\text { open space area }\left(\mathrm{A}_{\mathrm{os}}\right) \text { area and perimeter }\left(\mathrm{P}_{\mathrm{os}}\right) \text {. }\end{array}$ & $\begin{array}{l}\mathrm{A}_{\mathrm{os}} \\
\mathrm{P}_{\mathrm{os}}\end{array}$ & $\mathrm{W}=\frac{1}{2}\left(\frac{\mathrm{P}_{\mathrm{os}}}{2}-\sqrt{\frac{\mathrm{P}_{\mathrm{os}}^{2}}{4}-4 \mathrm{~A}_{\mathrm{os}}}\right.$ \\
\hline$\sigma_{\mathrm{H}}$ & $\begin{array}{l}\text { Building height } \\
\text { standard deviation }\end{array}$ & $\begin{array}{l}\text { Standard deviation of building heights } \\
\text { wheren } \text { }_{\mathrm{b}} \text { represents the number of buildings in the } \\
\text { city block. }\end{array}$ & $\begin{array}{l}\mathrm{H} \\
\mathrm{n}_{\mathrm{b}} \\
\mathrm{h}_{\mathrm{i}}\end{array}$ & $\sigma_{\mathrm{H}}=\sqrt{\frac{\left(\mathrm{h}_{\mathrm{i}}-\mathrm{H}\right)^{2}}{\mathrm{n}_{\mathrm{b}}}}$ \\
\hline $\mathrm{H} / \mathrm{W}$ & Aspect ratio & $\begin{array}{l}\text { Ratio of the average buildings height }(\mathrm{H}) \text { to the } \\
\text { street width }(\mathrm{W}) \text {. }\end{array}$ & $\begin{array}{l}\mathrm{H} \\
\mathrm{W}\end{array}$ & $\mathrm{H} / \mathrm{W}=\frac{\mathrm{H}}{\mathrm{W}}$ \\
\hline $\mathrm{D}_{\mathrm{B}}$ & Built-up density & Total building area to city block area ratio $\left(\mathrm{A}_{\mathrm{REF}}\right)$. & $\mathrm{a}_{\mathrm{b}_{\mathrm{i}}}$ & $\mathrm{D}_{\mathrm{B}}=\frac{\sum \mathrm{a}_{\mathrm{b}_{\mathrm{i}}}}{\mathrm{A}_{\mathrm{REF}}}$ \\
\hline $\mathrm{D}_{\mathrm{F}}$ & Facade density & $\begin{array}{l}\text { Total facade area }\left(A_{F}\right) \text { to total the envelope area } \\
\left(A_{R E F}+A_{F}\right) \text {. }\end{array}$ & $\mathrm{A}_{\mathrm{F}}$ & $D_{F}=\frac{A_{F}}{A_{R E F}+A_{F}}$ \\
\hline FSI & $\begin{array}{l}\text { Plot ratio or floor } \\
\text { space index }\end{array}$ & $\begin{array}{l}\text { Ratio between to the total gross floor area allowed } \\
\text { and plot area available }\left(A_{\mathrm{REF}}\right) \text {. }\end{array}$ & $\begin{array}{c}A_{\text {REF }} \\
a_{b_{i}} \\
h_{i}\end{array}$ & $\mathrm{FSI}=\frac{\sum \mathrm{a}_{\mathrm{b}_{\mathrm{i}}} \frac{\mathrm{h}_{\mathrm{i}}}{3}}{\mathrm{~A}_{\mathrm{REF}}}$ \\
\hline $\mathrm{D}_{\text {Flin }}$ & $\begin{array}{l}\text { Linear of facade } \\
\text { density }\end{array}$ & $\begin{array}{l}\text { Ratio of the sum of building perimeter }\left(\mathrm{p}_{\mathrm{i}}\right) \text { to total } \\
\text { city block area }\left(\mathrm{A}_{\mathrm{REF}}\right) \text {. }\end{array}$ & $\begin{array}{c}\mathrm{p}_{\mathrm{i}} \\
\mathrm{A}_{\mathrm{REF}}\end{array}$ & $\mathrm{D}_{\mathrm{Flin}}=\frac{\sum \mathrm{p}_{\mathrm{i}}}{\mathrm{A}_{\mathrm{REF}}}$ \\
\hline
\end{tabular}


Table 3. Geographical indicators averages and standard deviations for Nantes.

The values for the analyzed samples are in italic

\begin{tabular}{|c|c|c|c|c|c|c|c|c|c|}
\hline & $\mathrm{A}_{\mathrm{REF}}$ & $\mathrm{H}$ & $\mathrm{W}$ & $\sigma_{\mathrm{H}}$ & $\mathrm{H} / \mathrm{W}$ & $\mathrm{D}_{\mathrm{B}}$ & $\mathrm{D}_{\mathrm{F}}$ & FSI & $\mathrm{C}$ \\
\hline Average & $2.41 \mathrm{ha}$ & $11.2 \mathrm{~m}$ & $17.3 \mathrm{~m}$ & $2,4 \mathrm{~m}$ & 1,1 & 0,27 & 0,41 & 1,07 & 1,26 \\
\hline $\begin{array}{c}\text { Standard } \\
\text { deviation }\end{array}$ & $2.06 \mathrm{ha}$ & $11.7 \mathrm{~m}$ & $16.1 \mathrm{~m}$ & $2,7 \mathrm{~m}$ & 1,1 & 0,27 & 0,37 & 1,06 & 1,20 \\
\hline
\end{tabular}

\subsection{Climatic indicators}

\subsubsection{Urban albedo computation based on the Solene model}

In order to characterize the radiative balance, the urban albedo (A) is computed from solar simulations on 230 city blocks with the Solene model (Vinet 2000; Miguet and Groleau 2002) ${ }^{7}$. Solene includes a sky model consisting of a radiation spectrum divided into solar radiation (0.3-2.5 $\mu \mathrm{m})$ and infrared thermal radiation $(2.5-18 \mu \mathrm{m})$. Only solar radiations are considered and decomposed it into diffuse and direct components. Multiple reflections are computed considering both lambertian and opaque surfaces. To focus on geometry influence, the same surface reflectivity value is set to 0.45 for all surfaces. A preliminary study showed that the urban albedo time dependency (time of the year) can be neglected. Consequently, only mean albedo values are considered. These mean albedos are actually the averages of albedo calculated over the day at the summer equinox (July 21), which appear to be the most relevant values when considering UHI issues.

Solar simulations are performed by successive steps. The first calculation stage, based on geometric procedures, determines the visibility considering solar masks between two meshed elements or between a meshed element and a sun location or a meshed element and a sky patch of

\footnotetext{
${ }^{7}$ http://www.cerma.archi.fr/?q=fr/node/80
} 
the sky vault model. It results in form factors. The second one calculates the solar energy received by each meshed element. The incoming solar radiation is computed with the model of Perez for clear sky conditions, with a direct solar radiation (predominant) and diffuse solar radiation (distributed on the sky vault). Then, the multiple reflections are computed by a radiosity method (Vinet 2000; Miguet and Groleau 2002). This step provides the net solar flux received by each mesh and the parts that are absorbed and reflected. At the end, we sum respectively the fluxes reflected by all the surfaces $\varphi R_{i}$ in the sky direction and the fluxes directly received (i.e. excluding the flux received after reflection) $\varphi \mathrm{I}_{\mathrm{i}}$. The urban albedo $\mathrm{A}$ is given by the ratio:

$\mathrm{A}=\frac{\sum \mathrm{SVF}_{\mathrm{i}} \mathrm{S}_{\mathrm{i}} \varphi \mathrm{R}_{\mathrm{i}}}{\sum \mathrm{S}_{\mathrm{i}} \varphi \mathrm{I}_{\mathrm{i}}}$

where $S_{i}$ is the mesh surface area, $S_{V F}$ represents the mesh element sky view factor.

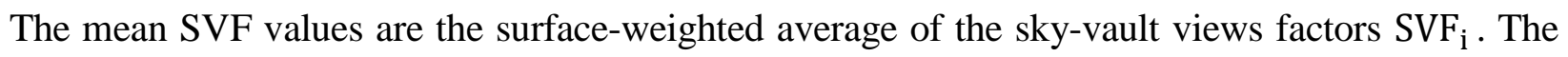
SVF at city block scale is given by:

$\mathrm{SVF}=\frac{\sum \mathrm{SVF}_{\mathrm{i}} \mathrm{S}_{\mathrm{i}}}{\sum \mathrm{S}_{\mathrm{i}}}$

Those two indicators are also separately computed for the three surface classes: roof, facade and ground surfaces (with the respective subscripts $R, F, G$ ).

Building modeling is necessary to compute solar radiation and inter-reflections within an urban shape. The building extraction process is illustrated by Figure 4. The geometry of each selected city block is extruded from building footprints contained in the BDTopo®. Buildings close to the studied city block are included in the solar mask domain. The geometrical model is a set of polygonal planar facets matching the external surfaces of the urban site: roofs, facades, courtyards and street grounds. A grid of $10 \mathrm{~m}^{2}$ triangular meshes is applied to these facets and calculations take place at the center of each mesh element. 


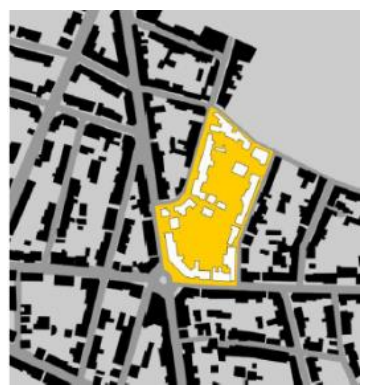

(1)

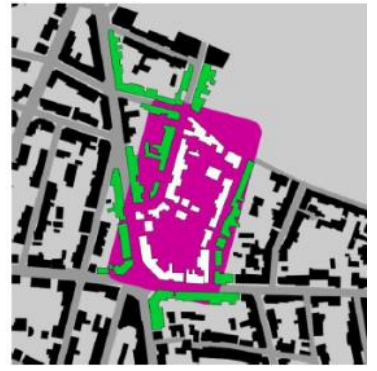

(2)

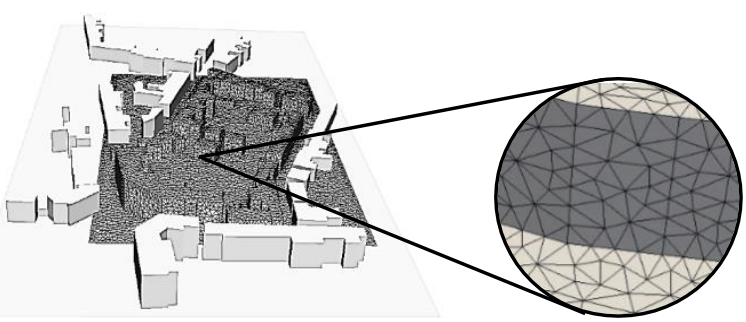

(3)

Figure 4. Building extraction jobstring: (1) selected city block (2) buffer and selected mask buildings

(3) meshed geometrical model (4) focus on triangular meshes

\subsubsection{Time shift temperature calculation based on cross-correlation analysis}

In order to characterize the heat storage properties of the urban fabric, the air temperature time shift $(\Delta \mathrm{t})$ is calculated from three years of measurements analysis. Nine temperature signals acquired every fifteen minutes are analyzed. A time shift is observed between each of them. A cross-correlation method is applied to calculate it. First, each signal is resampled every three minutes by interpolation. Then a reference signal $y(t)$ is chosen and shifted by a time $\tau$. The crosscorrelation function $\mathrm{C}_{\mathrm{xy}}(\tau)$ between $\mathrm{y}(\mathrm{t})$ and each of the station signals $\mathrm{x}(\mathrm{t})$ is calculated:

$C_{x y}(\tau)=\int x(t) y(t-\tau) d t$

Thus, eight cross-correlation functions as the one shown on Figure 5 are obtained. The time shift $(\Delta \mathrm{t})$ between each signal and the reference signal is defined when the cross-correlation function is maximal: $\mathrm{C}_{\mathrm{xy}}(\Delta \mathrm{t})=\mathrm{C}_{\mathrm{xy}} \mathrm{max}_{\max }$.

The TRH 11 site is taken as the reference signal because it is the least urbanized station, judged on the geographical indicators given in Table 1 (low facade density, low aspect ratio, etc).Calculations are performed for each month during the three years measurement period. 


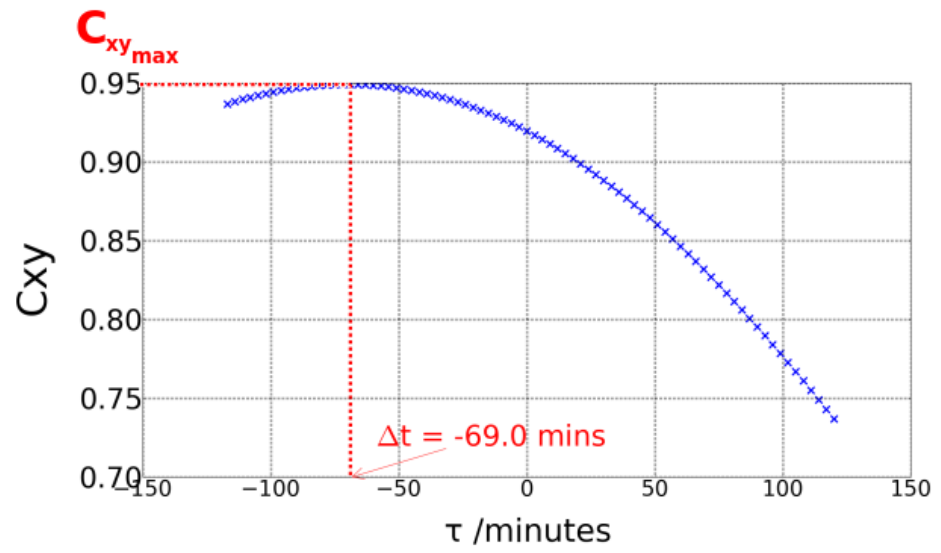

Figure 5. Cross correlation function between $\mathrm{x}(\mathrm{t})(\mathrm{TRH} 04)$ and the reference signal $\mathrm{y}(\mathrm{t})$ (TRH 11) for June 2012

\section{Results and discussions}

Simple linear regressions are performed to determine the most explicative geographical indicators of $\mathrm{A}$ and $\Delta \mathrm{t}$. A separate analysis is performed on each climatic indicator. The results are compared through a cross-analysis for a better understanding of interactions between urban environment and local climate conditions. Climatic maps are produced to illustrate the application of the methodology developed in this paper (see Figure 1).

\subsection{Influence of urban morphology on urban albedo values: a simulation-based analysis}

Each point of Figures 6 a) and Figures 6 b) represents the results of each city block. The results obtained over the daytime are not presented here because amplitudes of the albedo diurnal variations are very low. Among all simulations the root-mean-square of the A diurnal variation is always less than $7.5 \%$ of its daytime average. More important, facade albedo $\left(A_{F}\right)$ variations represent up to $26 \%$ of its average. The root-mean-square of average daytime $A_{F}$ can be related to urban shape. Figure 6 a) clearly shows a strong relationship between these variations and the average building height $\left(R^{2}=0.741\right)$ : the root-mean-square of $A_{F}$ daytime average increases with the building height rise. Other relationships can be highlighted between ground albedo $\left(A_{G}\right)$ variations and facade density $\left(D_{F}\right)\left(R^{2}=0.588\right)$ and a weaker between roof albedo $\left(A_{R}\right)$ variations and building height standard deviation $\left(\mathrm{R}^{2}=0.373\right)$. 


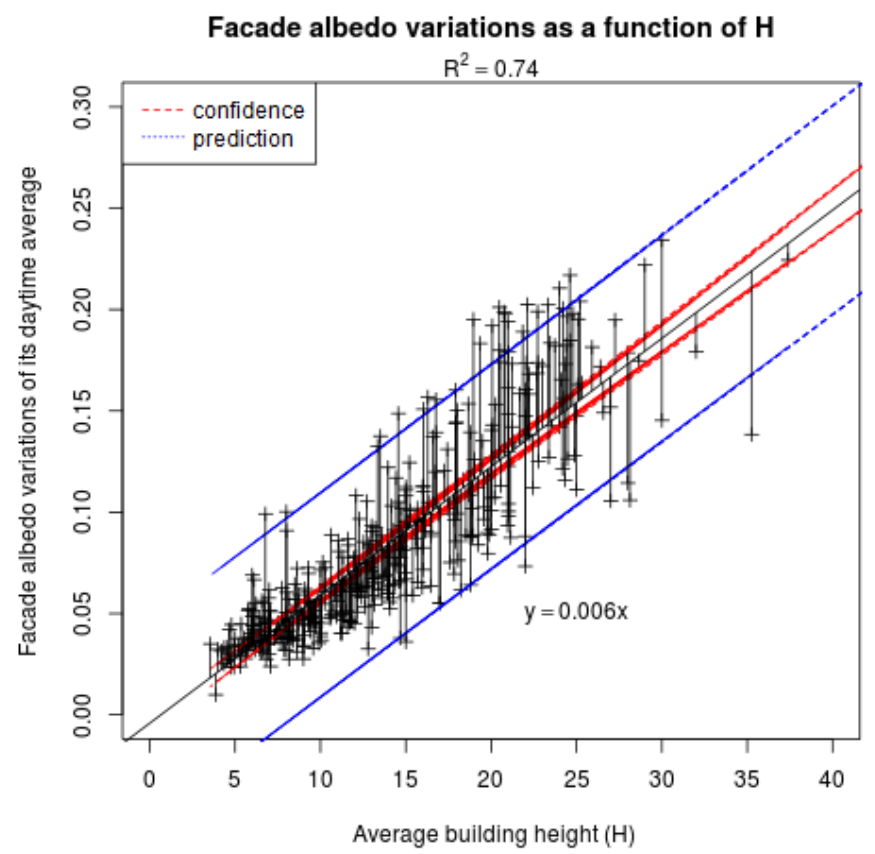

(a)

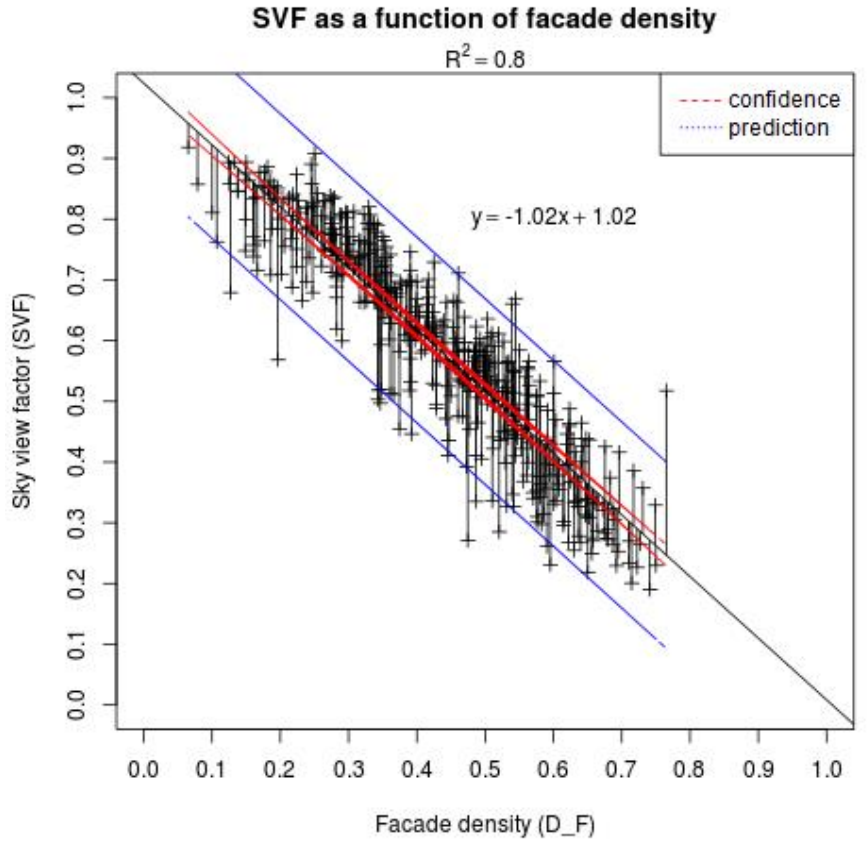

(b)

Figure 6. a) Facade albedo variation of its daytime average b) Linear regression between SVF and DF 
The A values depend primarily on the city block SVF: the A decreases with the decreasing SVF $\left(\mathrm{R}^{2}=0.939\right)$ caused by the solar energy trapping. Solar absorption increasing is directly related to multiple reflections between the facades and the ground. As presented in Figure. $6 \mathrm{~b}$ ) SVF is well explained by $\mathrm{D}_{\mathrm{F}}\left(\mathrm{R}^{2}=0.804\right)$. There is a strongly inter-dependency between FSI, H/W and SVF but $D_{F}$ has the highest coefficient of determination of all the non-dimensional geometric factors. Groleau and Mestayer (2013) showed that the mean sky-view factor of the whole city block surface (SVF) is closely related to $\mathrm{D}_{\mathrm{F}}$ and can be approximated by the simple relationship $\mathrm{SVF}=1-\mathrm{D}_{\mathrm{F}}$. That trend is consolidated through our investigations by extension to real urban fabric geometries.

Other geographical indicators influence on the A and the SVF values. The facade sky view factor $S_{F}$ is related to the average building height $H\left(R^{2}=0.618\right)$. There are negative relationships between the ground sky view factor $\mathrm{SVF}_{\mathrm{G}}$ and building density $\mathrm{D}_{\mathrm{B}}\left(\mathrm{R}^{2}=0.640\right)$ and between the $\mathrm{A}$ and $\mathrm{D}_{\mathrm{B}}\left(\mathrm{R}^{2}=0.579\right)$.

Some residual values between calculated and predicted the A or the SVF values are high. The six concerned city blocks are investigated to better understand those differences. All those city blocks present a particular geometry which explains those unexpected values: five of them consist in a unique building (a tower for example) whereas for the last one the ground is missing (due to a defect in geometry modeling). When these six particular cases are ignored, a better correlation is obtained between $S V F$ and $D_{F}\left(R^{2}=0.812\right.$ instead of $R^{2}=0.804$ previously). 


\subsection{Influence of urban forms on the thermal inertia phenomenon: an observation- based analysis}

Calculated by month, the results are sorted by season and presented in Figure 7 to study the impact of the solar radiation (which varies along a year) on the air temperature time shift.

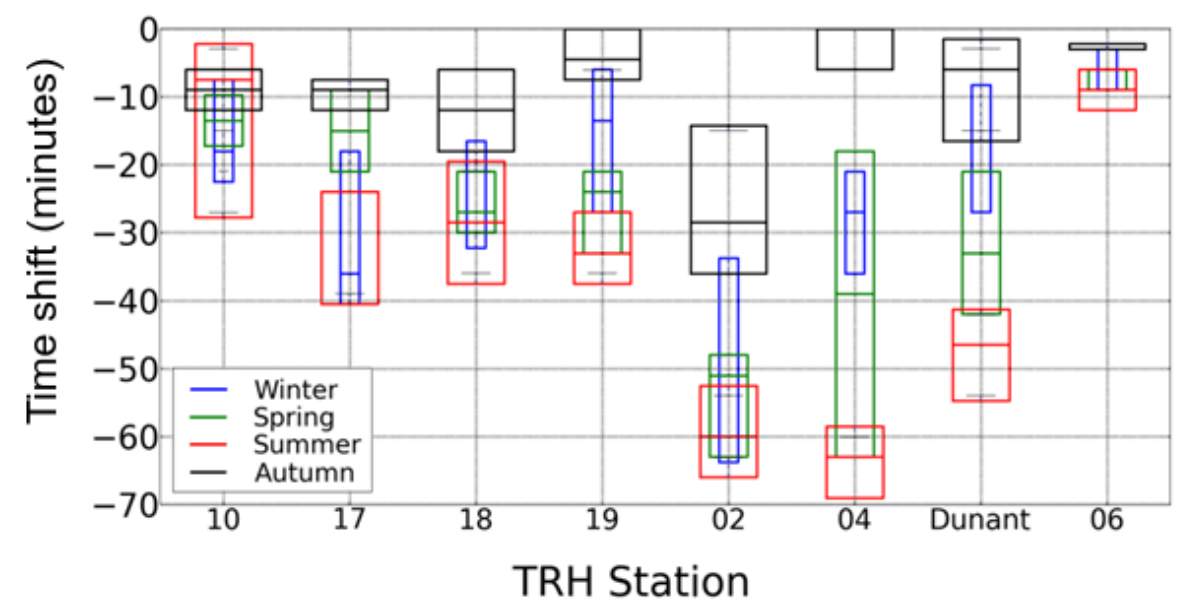

Figure 7. Air temperature time shifts $(\Delta t)$ observed seasonally for each station when TRH 11 is taken as reference. The extremity of the boxes are the first and third quartiles and the middle line is the median

Two main kinds of behavior are highlighted. Sites TRH 10 and TRH 06 have almost no seasonal time shift variation with the reference station. Almost all of the six others have a lower time shift during spring and summer time than during autumn and winter time. The average sizes of the boxes (interquartile) differ depending on the season analyzed. The average size is higher for spring (14 min) and winter (16 min) than for summer (11 $\mathrm{min})$ and autumn (8 $\mathrm{min})$.

Linear regression analysis are used to identify geographical indicators which best explain the range in $\Delta t$ values. The coefficient of determination $\mathrm{R}^{2}$ is the highest during summer time (when UHI effect is the most problematic). For this season, $\Delta \mathrm{t}$ is explained by the aspect ratio $\mathrm{H} / \mathrm{W}\left(\mathrm{R}^{2}=0.524\right)$. Figure 8 illustrates this relationship. 


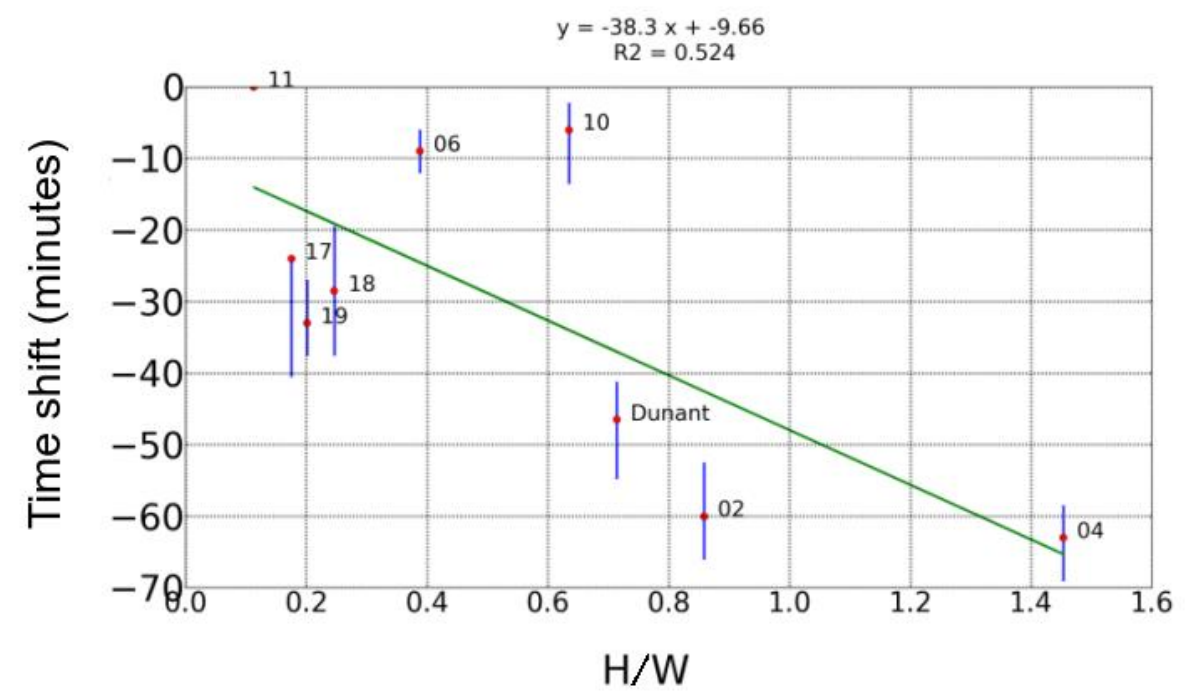

Figure 8. Linear regression between summer time shift and aspect ratio. Blue line : first and third quartile, Red dot : median.

Other geographical indicators are explicative of $\Delta \mathrm{t}$ - the linear of facade density $\mathrm{D}_{\text {Flin }}\left(\mathrm{R}^{2}=0.472\right)$ and the facade density $\mathrm{D}_{\mathrm{F}}\left(\mathrm{R}^{2}=0.451\right)$ - but they are highly correlated with $\mathrm{H} / \mathrm{W}\left(\mathrm{R}^{2}=0.890\right.$ between $\mathrm{H} / \mathrm{W}$ and $\mathrm{D}_{\text {Flin }}$ and $\mathrm{R}^{2}=0.950$ between $\mathrm{H} / \mathrm{W}$ and $\mathrm{D}_{\mathrm{F}}$ ). Considering those results, the height of the facades is not a determinant factor to explain $\Delta t\left(\mathrm{R}^{2}=0.132\right)$.

\subsection{Cross-analysis of climatic indicators}

Radiative balance at city block scale (and thus A) is the consequence of shade/sunshine percentage that is directly linked to the urban shape and then to the SVF. Density and height of buildings modify direct shading but $\mathrm{D}_{\mathrm{F}}$ is the best explanatory non-dimensional geometrical parameter to characterize SVF and A. The solar radiation intensity (due to the course of the sun along the year) and the sunshine duration (due to the weather and the course of the sun along the year) also impact the seasonal $\Delta \mathrm{t}$ results (see Figure 7). The amount of heat stored depends on incident solar radiation thus $\Delta \mathrm{t}$ can be related to the solar balance. As observed for $\mathrm{A}, \mathrm{D}_{\mathrm{F}}$ is also one of the best explanatory geographical indicators to characterize $\Delta \mathrm{t}$. 
The thermal inertia is more impacted by $\mathrm{D}_{\text {Flin }}$ than by $\mathrm{D}_{\mathrm{F}}$. This statement might be explained by the shadow influence of high buildings on solar absorption. When $\mathrm{H}$ and thus $\mathrm{D}_{\mathrm{F}}$ are high, the energy is less absorbed at the bottom part of the facades (where the temperature is measured) than at the high parts. The amount of solar energy absorbed also depends on the buildings orientation. The main orientation of the city blocks where are located the sensors may then play a major role on the air temperature when $\mathrm{H}$ is high. This assumption is consistent with the results presented on Figure 6 a): the root-mean-square of facade albedo daytime average increases with the building height rise.

Climatic maps can be produced from the best relationships highlighted between climatic and geographical indicators:

$\mathrm{A}=-0.21 \mathrm{D}_{\mathrm{F}}+0.45$

$\Delta \mathrm{t}=-38.3 \mathrm{H} / \mathrm{W}-9.66$

The first map (Figure 9 a)) represents the potential of solar trapping effect with urban albedo estimations at city block scale. The second map (Figure 9 b)) assesses the heat storage potential at city block scale given by the $\Delta$ t estimation. The spatial distributions of the two climatic indicators are well correlated. It confirms that the amount of heat stored can be related to solar energy absorption by urban fabric. The Nantes city center is particularly vulnerable to solar trapping effect and has a high heat storage potential (in brown on Figures 9). The UHI potential decreases with the distance to the city center. Nevertheless some of the city center areas have low building density which could create "local cool islands" (in green on Figures 9). 


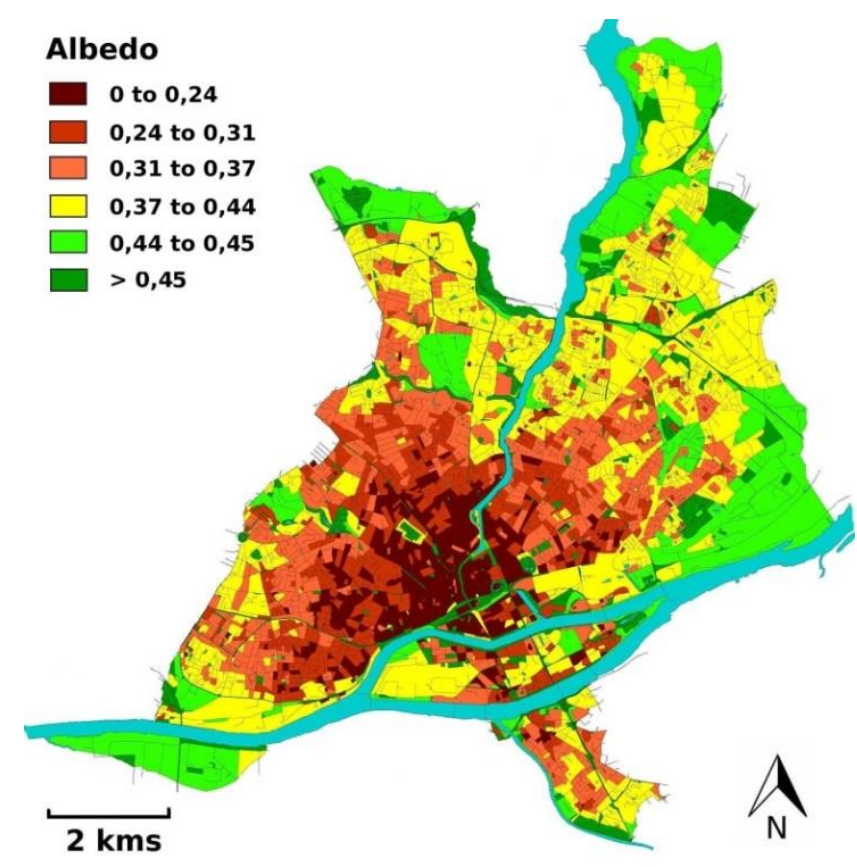

(a)

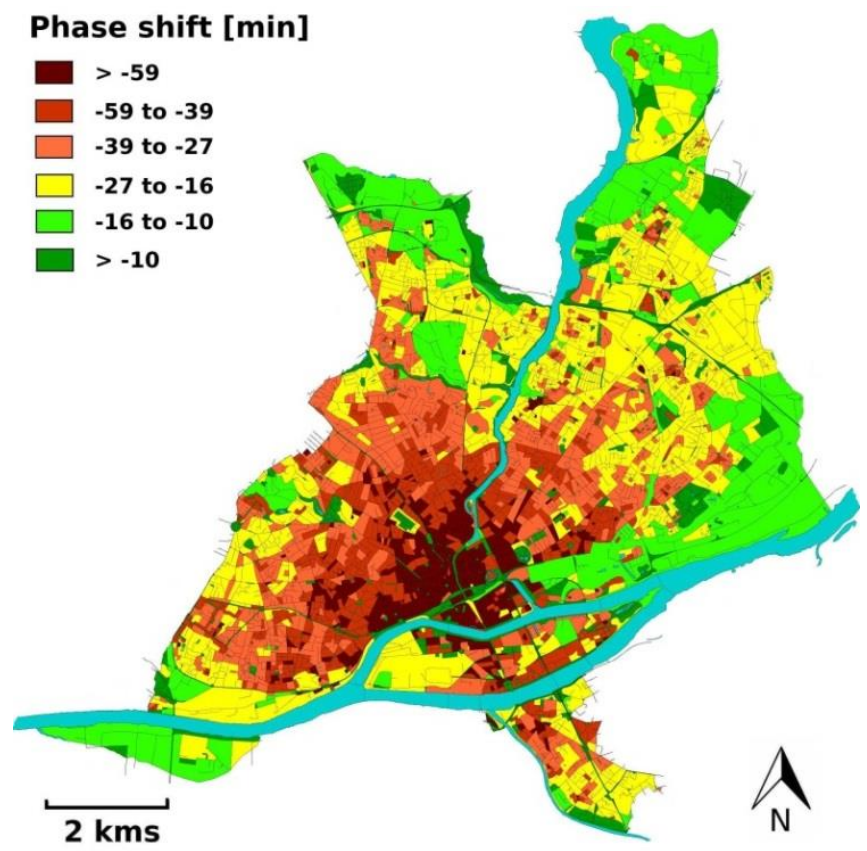

(b)

Figure 9. Spatial distribution of a) urban albedo and b) temperature signal time shift computed at city block scale 


\subsection{From feedback to future works}

Urban climate distribution is strongly related to urban shape (Oke 1987) but also depends on the thermal characteristics of urban surfaces. Different sources of geographical data may be used. Concerning the urban shape, the level of detail (LOD) could be improved differentiating roof structures (LOD 2 in CityGML standards) for the A analysis. This data is not yet available, but several approaches tend to produce 3D building geometries (Hammoudi and Dornaika 2010) which will be interesting for future analysis. Concerning the urban surface composition, the land use maps derived from remote sensing images provide a better spatial distribution of vegetal areas (Long et al. 2014) than BDTopo®. The vegetation density indicator could be taken into account in future analysis of relationships between climatic and geographical indicators. Thermal characteristics of urban surfaces are not considered here because of the absence of data at city scale (the same surface reflectivity value is set in A analysis). Consequently scenarios of urban surface composition can be proposed to differentiate the urban typologies (Bonhomme et al. 2014).

To complete this analysis, anthropogenic fluxes (due to traffic and building energy consumption) and the buffer influence of rivers and parks should be taken into account to assess the urban vulnerability to UHI (Spronken-Smith and Oke 1998).

The data accuracy and the methodology used for $\Delta t$ analysis are open to criticism. Several ways to improve the methods developed in this paper are proposed:

- Many of the sites used for our study are set on a wall. This position decreases the natural convection of the sensor, which may lead to an overestimation of the air temperature (Oke 2004). This phenomenon is particularly pronounced during certain hours of the day, when the sun directly hits the wall and the sensor shield. The time shift calculated in this paper should illustrate the value of a whole city block. However, the temperature measured by most of the sensors are certainly also correlated to the wall temperatures where they are set, thus being potentially source of error. This error might be estimated in order to correct the values recordered when the sun hits both the sensor shield and the wall. Poles might be used to set future sensors in order to avoid this overheating phenomenon. 
- The shape, the size and the orientation of the city blocks may differ a lot between two measurement sites, which would induce different site behaviors (depending on the wind direction for example). The geographical indicators should be calculated using circle buffer analysis instead of city block analysis to better represent the sensor surroundings. City block remain nevertheless the elementary spatial unit for climate map production.

- The number of sensors should be higher to perform a highly trustable linear regression.

- The method used in this article for $\Delta t$ calculation can be more accurate. Several others methods like the generalized correlation method (Knapp and Carter 1976) could be used for a better estimation of the $\Delta \mathrm{t}$.

A multi-regression analysis using many geographical indicators could be performed for both temperature $\Delta \mathrm{t}$ and $\mathrm{A}$ analysis. It could better explain climatic indicators by taking into account dependency between each geographical indicator.

Finally, the method used to produce the climatic maps should be applied to several others areas in order to verify its reproducibility. It will be interesting to test the method on the city of Nancy and compare the results with the Local Climate Zones (LCZ) built by Leconte et al. (2015).

\section{Conclusions}

This paper has demonstrated the influence of several geographical indicators on two climatic indicators: the air temperature time shift and the urban albedo. The Nantes territory was partitioned into elementary spatial units called city blocks both for geographical and climatic analysis. Geographical indicators were calculated from the BDTopo® using the OrbisGIS platform. The urban albedo was calculated using the Solene model from ten percent of the city blocks contained in the whole studied area. The time shift was calculated from air temperature measurements recorded during three years at nine measurement sites. Linear regression analysis were used to identify the geographical indicators that best explain the climatic indicators. The facade density and the aspect ratio are respectively the most explanatory indicators of the urban albedo and the air temperature time shift. 
The results of this study can be useful for the urban planners to adapt cities to climate change: (1) climatic maps (of albedo combined with heat storage properties) for diagnostic stage can be produced from the main geometrical indicators highlighted in this article: the facade density and the aspect ratio. (2) It is although suggested that by optimizing local geographical indicators, the impact of urbanization on UHI can be greatly modified.

\section{Acknowledgements}

This work was supported by the French Environment and Energy Management Agency (ADEME) and AgroCampus Ouest (ACO). The authors wish to thank the OrbisGIS team for their technical support and advices: http://www.orbisgis.org/about/the-team/.

\section{References}

Arnfield, A. J., and Grimmond, C. S. B. 1998. "An urban canyon energy budget model and its application to urban storage heat flux modeling." Energy and buildings 27(1): 61-68.

Berghauser Pont, M., and Haupt., P. 2005. "The Spacemate: density and the typomorphology of the urban fabric", Nordic journal of architectural research 4: 55-68.

Bocher, E., and Petit, G. 2012. "OrbisGIS : Geographical Information System designed by and for research", Innovative Software Development in GIS, ISTE \& Wiley, "Geographical Information System" series, Bucher B. \& Le Ber F Editors: 25-66.

Bonhomme, M., Masson, V., Adolphe, L. 2014. "GENIUS: A tool for classifying and modelling evolution of urban typologies - Part 1 Synchronic Modelling ". Environment and Planning B: Planning and Design - submitted

Gal, T., Lindberg, F., and Unger, J. 2009. "Computing continuous sky view factors using 3D urban raster and vector databases: comparison and application to urban climate." Theoretical and applied climatology 95(1-2): 111-123. 
Groleau, D., and Mestayer, P. G. 2013. "Urban Morphology Influence on Urban Albedo: A Revisit with the Solene Model." Boundary-Layer Meteorology 147 (2): 301-327.

Hammoudi, K., and Dornaika, F. 2010. "A featureless approach to 3D polyhedral building modeling from aerial images." Sensors 11(1): 228-259.

Knapp, C., and Carter, G. C. 1976. "The generalized correlation method for estimation of time delay." Acoustics, Speech and Signal Processing, IEEE Transactions, 24(4): 320-327.

Kondo, A., Ueno, M., Kaga, A., and Yamaguchi, K. 2001. "The influence of urban canopy configuration on urban albedo." Boundary-Layer Meteorology 100(2): 225-242.

Leconte, F., Bouyer J., Claverie, R., Pétrissans, M. 2015. "Using Local Climate Zone scheme for UHI assessment: Evaluation of the method using mobile measurements." Building and Environment 83 :39-49.

Lesbegueries, J., Lachiche, N., Braud, A., Skupinski, G., Puissant, A., and Perret, J. 2009. "A platform for Spatial Data Labeling in an Urban Context." Presentation at the International Opensource Geospatial Research Symposium 2009 - OGRS09.

Long, N., and Kergomard., C. 2005. "Classification morphologique du tissu urbain pour des applications climatologiques" Revue Internationale de Géomatique 15: 487-512.

Long, N., Bellec, A., Bocher, E., Petit, G. 2014. " Influence of the methodology (pixel-based vs object-based) to extract urban vegetation from VHR images in different urban zones. " 5th Presentation at the Geobia Conference.

Masson, V., Marchadier, C., Adolphe, L., Aguejdad, R., Avner, P., Bonhomme, M., Bretagne, G., Briottet, X., Bueno, B., De Munck, C., Doukari, O., Hallegatte, S., Hidalgoa, J. , Houetc, T., Le Bras J., Lemonsu, A., Long, N., Moine, M.-P., Morel T., Nolorgues L., Pigeon, G., Salagnac J.-L., Viguié V., Zibouche, K. (2014). "Adapting cities to climate change: a systemic modelling approach". Urban Climate 10(2):407-429. 
Miguet, F., and Groleau, D. 2002. "A daylight simulation tool for urban and architectural spaces application to transmitted direct and diffuse light through glazing." Building and environment 37(8): 833-843.

Musy, M., Gutleben C., Inard C., Long N., Mestayer P., Rodriguez F., and Rosant J. M. 2012. "VegDUD project: Role of vegetation in sustainable urban development." Presentation at the 8th International Conference on Urban Climate and 10th Symposium on the Urban Environment. Dublin.

Oke, T. R. 1987. "Boundary layer climates." Ed. Routledge.

Oke, T. R. 2004. "Initial guidance to obtain representative meteorological observations at urban sites." Geneva: World Meteorological Organization 2004.

Ruban, V., Rodriguez, F., Rosant, J. M., Larrarte, F., Joannis, C., Mestayer, P., and Andrieu, H. 2007. "Hydrologic and energetic experimental survey of a small urban watershed." Presentation at the NOVATECH conference.

Schwarz N., Schlink U., Franck U., Großmann K., 2012. "Relationship of land surface and air temperatures and its implications for quantifying urban heat island indicators - An application for the city of Leipzig (Germany)." Ecological Indicators 18: 693-704

Spronken-Smith, R. A., and Oke, T. R. 1998. "The thermal regime of urban parks in two cities with different summer climates." International journal of remote sensing 19(11): 2085-2104

Spronken-Smith, R. A., and Oke, T. R. 1999. "Scale modelling of nocturnal cooling in urban parks. " Boundary-Layer Meteorology, 93(2): 287-312.Stocker, T. F., Qin, D., Plattner, G. K., Tignor, M., Allen, S. K., Boschung, J., and Midgley, P. M. 2013. "Climate change 2013: the physical science basis." Contribution of working Group I to the fifth assessment report of the intergovernmental panel on climate change. 
Unger, J. 2004. "Intra-urban relationship between surface geometry and urban heat island: review and new approach." Climate research 27: 253-264.

Vinet, J. 2000. "Contribution à la modélisation thermo-aéraulique du microclimat urbain. Caractérisation de l'impact de l'eau et de la végétation sur les conditions de confort en espaces extérieurs" Doctoral dissertation, Université de Nantes.

Yan, H., Fan, S., Guo, C., Wu, F., Zhang, N., \& Dong, L. 2014. "Assessing the effects of landscape design parameters on intra-urban air temperature variability: The case of Beijing, China." Building and Environment, 76, 44-53. 